\title{
Construction of Green Credit System for Commercial Banks
}

\author{
Zhou Meimei \\ Xidian University, School of Economics and Management, Xi'an 710126, China
}

\begin{abstract}
With the rapid development of economy and the expansion of industry, the environmental pollution and ecological deterioration have become increasingly prominent, and the green economy has become the trend of international development. Green credit, as an important financial tool of green economic development, aims to persist in the sustainable development of economy and environment in the field of financial activities. Although China's commercial banks have achieved some success in developing green credit, there are still many difficulties and difficulties in practice. This paper expounds the practice and difficulties of developing green credit by commercial banks in china, and analyzes the reasons why green credit is difficult to implement from the point of view of game theory. Finally, some suggestions are put forward to provide reference for the healthy development and effective operation of green credit business.
\end{abstract}

Keywords: Commercial Banks; Green credit; Game theory; System construction

\section{Introduction}

As the booster of economic growth of a country, finance is the middle bridge to realize the sustainable development of economy, finance and environment. In order to build a green financial system and promote the development of green economy, China has continued to introduce new financial services such as green credit, green securities and green insurance. As the main form of green finance, Green credit is still in the growth stage. In recent years, the environmental awareness of commercial banks in China has been strengthened, and green credit has been actively implemented under the guidance of government policies. However, there are still some problems, such as imperfect credit rating system, low level of environmental risk management and lack of strict legislative guarantee measures. Therefore, it is necessary to further explore the path of development of commercial banks of green credit, perfect green credit rating system, raising the level of risk management, establish relevant system from the legislative level, to lead the green credit to contribute to the sustainable development of economy.

\section{Theoretical and Literature Review}

Green credit belongs to the category of sustainable finance, in essence, commercial banks provide financing opportunities for enterprises and projects that meet environmental protection standards, so as to control the credit line of high energy consuming and highly polluting industries, and promote the development of green economy. The fundamental goal is to combine the financial industry and environmental protection, improve the awareness of energy saving and emission reduction, the extensive mode of development to reverse the environmental pollution, waste of resources, to prevent a vicious spiral after pollution, pollution and Governance.

The development of green credit has deep theoretical support in the aspects of economy, society and environment.
The following two aspects explain the theoretical basis of green credit development from environmental economics and corporate environmental responsibility.

\subsection{Theoretical analysis}

\subsubsection{Environmental economics}

The key problem of environmental economics is to realize the purpose of saving resources and protecting environment through economic means. The dislocation development of environment and economy will lead to market failure. Green credit is a typical application of environmental economics and an economic means introduced by the government to regulate market failure. Commercial banks through the implementation of the credit system of rewards and punishments support the green industry and limit pollution enterprises from the loan size and interest rates, continuously strengthen the incentive mechanism of enterprise control, gradually promote the sewage cost internalization.

\subsubsection{Corporate environmental responsibility}

As a special enterprise organization, the commercial bank takes the responsibility of environmental protection into the construction of the institution. The commercial bank is in addition to the general enterprise's energy saving and emission reduction environmental responsibility, not only through the credit tool to control the pollution behavior of enterprises to change the mode of economic development, but also through the implementation of the green financial policy to adjust the economic structure.

\subsection{Literature Review}

With the arrival of green development upsurge, the research literature about green finance is increasing. For example, An Wei (2008) believes that the green credit system should be improved from the aspects of rules and regulations, management system, risk control and information sharing. Ren Hui (2009) believes that financial institutions should introduce diversified green financial instruments and set up 


\section{International Journal of Science and Research (IJSR) \\ ISSN (Online): 2319-7064}

Index Copernicus Value (2015): 78.96 | Impact Factor (2015): 6.391

ecological civilization consciousness. Du Li, Zhang Xin (2012) believes that green finance is not only conducive to optimizing the bank's loan structure and enhancing competitiveness, but also to promote industrial green transformation. Research group of the people's Bank of China (2013) empirically tests the role of green credit in industrial restructuring and upgrading, and shows that the increase and decrease of green credit is positively related to energy consumption in enterprises. Dong Xin (2015) holds that the financial institutions in China have a cognitive bias towards green finance and a weak sense of ecological civilization, which seriously restricts the development of green economy. Yu Lan (2016) believes that China's green financial development is faced with imperfect institutional mechanisms, green financing products in a single form, lack of innovation.

Overall, the existing research not only enriched the theoretical system of green finance, but also provided a reference for promoting green development. But the research on green credit is less, and the theory is lack of verification and practice. Therefore, this paper based on the theory of green credit, combined with the stage of commercial banks to implement green credit practices, through the game theory test of green credit dilemma, so as to lay the foundation for the construction of modern green financial system.

\section{Situation and Difficulties Analysis}

Under the guidance of government policy, China's commercial banks actively implement green credit business, and have achieved some success in practice, but there are still many difficulties and shortcomings in the actual operation of green credit.

\subsection{Present situation analysis}

In recent years, China's commercial banks have actively explored and tried to develop green credit. The ICBC put forward the idea of "green credit" in 2007 for the first time163 and formulated the "green credit development strategy" in August 2015. CIB pioneered the introduction of "energy efficiency loan" products in China and issued the first single national green financial credit asset backed securities. CMB actively carried out intermediate credit, emission rights mortgage loans, energy-saving income pledge loans and other innovative products. From table 1 shows that China's representative commercial banks' green credit balance has increased year by year, and achieved good results. According to CBRC statistics, the 21 major banking institutions green credit balance reached 7.26 trillion Yuan as of the first half of 2016, accounting for $9 \%$ of the loans, including energy saving and environmental protection, new energy, new energy vehicles and other strategic emerging industries loans 1.69 trillion Yuan, energy saving and environmental protection projects and services loans 5.57 trillion Yuan. It can be seen that the implementation of green credit has greatly promoted the development of green economy.

Table 1: Green credit balance Unit: Billion Yuan

\begin{tabular}{|l|l|l|l|l|l|}
\hline Banks & 2012 & 2013 & 2014 & 2015 & 2016 \\
\hline ICBC & 5934.00 & 5980.00 & 6552.81 & 7028.43 & 9785.60 \\
\hline CBC & 2396.37 & 4883.70 & 4870.77 & 7335.63 & 8892.21 \\
\hline BC & 2274.80 & 2588.00 & 3010.00 & 4123.00 & 4673.00 \\
\hline ABC & 1522.00 & 733.98 & 4724.47 & 5432.31 & 6494.32 \\
\hline CMBC & 1200.00 & 1163.72 & 1509.47 & 1565.03 & 1436.64 \\
\hline
\end{tabular}

\subsection{Difficulties analysis}

In the current financial environment, As China has not yet established a clear green credit system, leading to commercial banks have the following difficulties in the implementation of the green process.

\subsubsection{Unsound green credit policy}

First of all, the problem of the policy itself, that is, the green credit policy is not targeted and operational, failed to grasp the environmental risk factors of enterprises, the lack of specific standards and management requirements. Secondly, the problem of policy implementation, that is, credit personnel do not pay enough attention to green credit, and lack the necessary professional skills to implement the policy requirements. Finally, the problem of credit management mechanism, figure 1 is the four aspect of the green credit management mechanism, but some commercial banks in China have blind credit phenomenon, which leads to the lack of efficiency and feasibility of the green credit management mechanism.

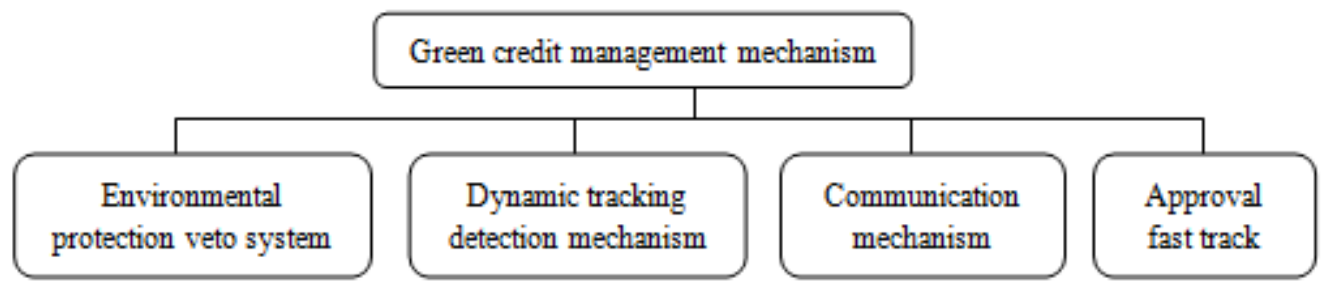

Figure 1: Green credit management mechanism

\subsubsection{Green credit products without innovation}

At this stage of the commercial banks of the green credit products remains to project loans, the lack of designing and marketing environmental protection enterprises personalized financial product or financial service scheme, especially the lack of studying contract energy management,

\section{Volume 6 Issue 7, July 2017 www.ijsr.net}




\section{International Journal of Science and Research (IJSR) \\ ISSN (Online): 2319-7064}

Index Copernicus Value (2015): 78.96 | Impact Factor (2015): 6.391

environmental protection products in government procurement and other emerging business models, failed to launch targeted credit products. This will lead to the growing gap of financing for environmental protection enterprises, thereby inhibiting the development of green economy.

\subsubsection{Low level of environmental risk management}

In the process of putting green credit into effect, the environmental risk faced by enterprises is an important basis for commercial banks to choose credit decisions. However, the low level of environmental risk management in China's commercial banks has become one of the important reasons that hinder the implementation of green credit by commercial banks. First of all, due to the low level of credit rating, it is impossible to judge the potential environmental risks faced by enterprises. Secondly, According to the environmental impact of loan customers and projects, commercial banks roughly classify loan enterprises into three categories: A, B and C. Finally, the environmental risk management of commercial banks is difficult to achieve dynamic management, and the loans that have been put out have not been tracked in a timely manner.

\subsubsection{Limited scale of green credit}

For a long time, under the restriction of traditional industrial structure, commercial banks have formed the credit structure with "manufacturing pollution" and "higher carbon emission". Energy saving and environmental protection projects often focus on small and medium enterprises with high scientific and technological content and long investment cycle, which leads to lower cost and income of commercial bank loans and low enthusiasm for loans. To a large extent, it cannot meet the needs of the environmental protection industry or enterprise loans, and has hindered the pace of industrial restructuring.

\section{Methodology}

From the perspective of game theory, the following analyzes the choice and equilibrium of the two major decision makers in banks and enterprises, and then comes to the basic reason why it is difficult for commercial banks to implement green credit in china. The assumptions are made before specific analysis as follows: bank lending income from standard enterprises is $R_{1}$ and from substandard enterprises is $\mathrm{R}_{2}$; the opportunity cost of polluting enterprises without loan is $C_{1}$. Polluting enterprises to obtain income after loans is $\mathrm{R}_{3}$, the income from other financing channels is $R_{4}$, the cost of pollution control is $C_{2}$, and the loss after being investigated is $\mathrm{C}_{3}$. The utility matrix of the game between banks and firms is shown in table 2 .

Table 2: Game matrix between banks and enterprises

\begin{tabular}{|c|c|c|}
\hline Type & Loan & Without loan \\
\hline Pollution & $\mathrm{R}_{3}-\mathrm{C}_{3}, \mathrm{R}_{2}$ & $\mathrm{R}_{4}-\mathrm{C}_{3}, \mathrm{C}_{1}$ \\
\hline Non pollution & $\mathrm{R}_{3}-\mathrm{C}_{2}, \mathrm{R}_{1}$ & $\mathrm{R}_{4}-\mathrm{C}_{2}, \mathrm{C}_{1}$ \\
\hline
\end{tabular}

\subsection{Pure strategic Nash equilibrium}

Because the cost of pollution control is usually higher than the cost of pollution and punishment, the dominant strategy of the enterprise is pollution $\left(\mathrm{C}_{2}>\mathrm{C}_{3}\right)$. "Two high" enterprises can continue to operate by paying fines, credit funds less security risks, so banks will choose to grant loans. The Nash equilibrium determined by the game is (pollution, loan).

\subsection{Mixed strategy Nash equilibrium}

The assumptions are as follows: the probability of pollution control and pollution is $\mathrm{P}_{1}$ and $1-\mathrm{P}_{1}$ respectively, and the probability of bank choosing loans and non loans is $\mathrm{P}_{2}$ and $1-\mathrm{P}_{2}$ respectively. Therefore, the expectation of "two high" enterprises is shown in (1):

$$
\begin{aligned}
& U_{1}=P_{1}\left[P_{2}\left(R_{3}-C_{2}\right)+\left(1-P_{2}\right)\left(R_{4}-C_{2}\right)\right]+ \\
& \left(1-P_{1}\right)\left[P_{2}\left(R_{3}-C_{3}\right)+\left(1-P_{2}\right)\left(R_{4}-C_{3}\right)\right]
\end{aligned}
$$

$$
\frac{\partial U_{1}}{\partial P_{1}}=C_{3}-C_{2}
$$

And the expectation of banks is shown in (4):

$$
\begin{array}{r}
U_{2}=P_{2}\left[P_{1} R_{1}+\left(1-P_{1}\right) R_{2}-C_{1}\left(1-P_{2}\right)\right] \\
\frac{\partial U_{2}}{\partial P_{2}}=P_{1}\left(R_{1}-R_{2}\right)+R_{2}+C_{1}
\end{array}
$$

\subsection{Result discussion}

As $\mathrm{R}_{2}$ has included the administrative penalties and other possible credit losses $\left(C_{2}>C_{3}\right)$, that is, $R_{2} \leq R_{1}$, the bank's payment increases with the increase of $\mathrm{P}_{2}$; While the payment of "two high" enterprises decreases with the increase of $\mathrm{P}_{1}$. In equilibrium, the mixed strategy is as follows: $P_{1}=0, P_{2}=1$. It can be seen that the Nash equilibrium under mixed strategy is also (pollution, loan).

In the above Nash equilibrium, the green credit policy is difficult to implement, because the enterprises and banks are pursuing their own maximum interests, environmental protection departments of polluting enterprises punishment system is implemented. In addition, the government's supervision mechanism is not in place, the bank credit system is imperfect and the "two high" enterprises are blind loans. Eventually, pollution and loans become the best strategic choice for enterprises and banks, thus contrary to the concept of sustainable development of green credit policy.

\section{Countermeasures}

In view of the effectiveness, difficulties and causes of the development of green credit in China's commercial banks, it is necessary to further improve the green credit system and 


\section{International Journal of Science and Research (IJSR) \\ ISSN (Online): 2319-7064}

Index Copernicus Value (2015): 78.96 Impact Factor (2015): 6.391

achieve a win-win situation between the economy and the environment.

\subsection{Improve the operability of green credit policy}

Based on the shortage of green credit policy in china, we can draw on the relevant provisions of the Equator Principle and establish a practical green credit business standard system. Commercial banks can increase the operational level of credit standards from the two areas of business and target customers' access standards, such as table 3, a normative example of the green credit business of commercial banks. Under the guidance of the policy, commercial banks should increase the scale of green credit, meet the needs of enterprises' energy saving and emission reduction projects, and actively encourage projects that meet the requirements of the green credit standard. For enterprises that do not meet the requirements of environmental protection and social responsibility, the granting of credit shall be subject to one vote veto.

Table 3: Green credit business areas

\begin{tabular}{|c|c|}
\hline \multicolumn{2}{|c|}{ Division of business segments of green credit } \\
\hline \multirow{2}{*}{$\begin{array}{c}\text { refinement } \\
\text { areas }\end{array}$} & $\begin{array}{c}\text { Saving and replacing oil Green lighting } \\
\text { Government agencies energy saving、 Energy } \\
\text { system optimization、 Energy saving } \\
\text { inspection and service system construction }\end{array}$ \\
\hline \multirow{3}{*}{ Key areas } & $\begin{array}{c}\text { Waste heat utilization、Coal fired boiler } \\
\text { reconstruction、Motor building energy } \\
\text { efficiency Combined heat and power }\end{array}$ \\
\hline
\end{tabular}

\subsection{Innovate the green credit system}

Commercial banks should constantly innovate green credit products and use various financial instruments to allocate funds reasonably according to the trend of economic development. First of all, the implementation of preferential lending rate policy is conducive to increasing support for low-carbon environmental protection, energy-saving emission reduction enterprises, in order to achieve sustained and healthy development of the social environment. Secondly, commercial banks should actively introduce green credit operations such as loan portfolios and derivatives to meet the needs of environmental protection and pollution control enterprises, so that energy-saving emission reduction projects can be carried out smoothly, and the transformation and development of the economy will be promoted.

\subsection{Improve the business cooperation mechanism}

The implementation of green credit business requires a lot of manpower, material and financial resources, such as project financing investigation and evaluation, the establishment of the functional departments and the expansion of credit products will increase the bank's operating costs. China's commercial banks can learn from the operation mode of the green credit products market in developed countries, and actively explore cooperation mechanism among policy banks, commercial banks and the government (Figure 2). With the help of policy banks and government, we can expand the scale of green credit and realize the concept of sustainable development.

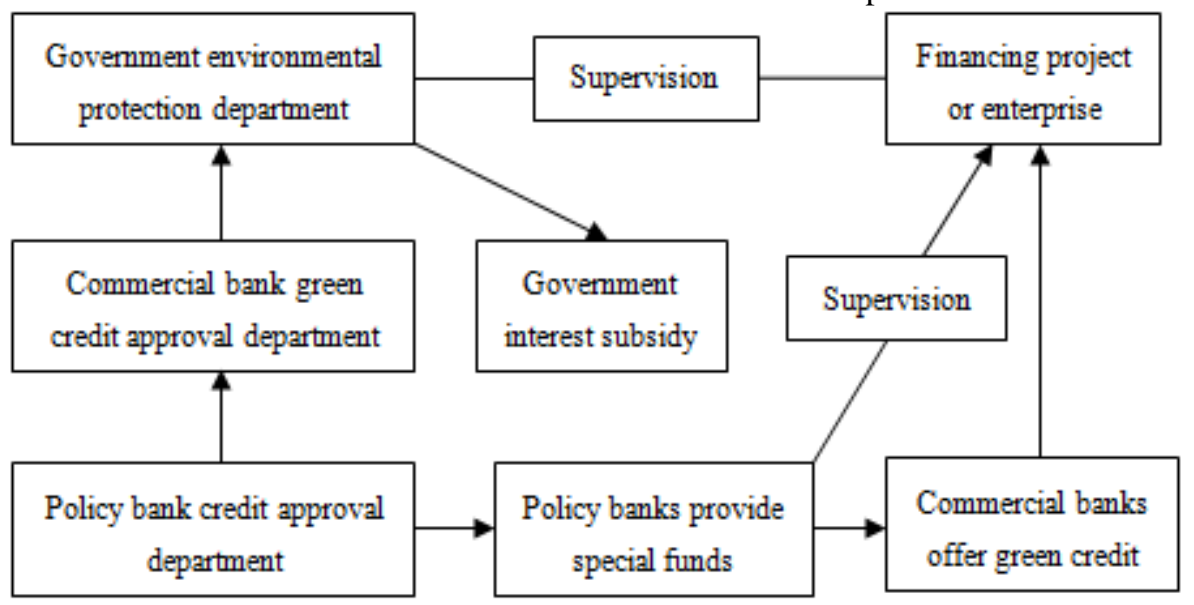

Figure 2: Green credit business cooperation mechanism

\subsection{Improve the level of environmental risk management}

Firstly, the banking financial institutions should focus on the risks that may arise to the social environment in the construction, production and operation activities of the clients and important related parties, and strictly investigate and evaluate the loan enterprises. Secondly, commercial banks should conduct strict pre loan review and assessment and abandon loans to enterprises substandard. Finally, commercial banks should be in a timely manner to understand the use of green credit, and in accordance with the different stages of environmental risk adjustment, so as to improve the level of environmental risk management of banks.

\section{Conclusions and Prospects}

Green credit has a good "green allocation" function to the fund and promotes the transformation of the polluting industries to the environmental protection high-tech industry. Although China's commercial banks to support the results achieved in the green credit system construction and environmental protection projects, but in practice there are imperfect policy operability, lack of product innovation and

Volume 6 Issue 7, July 2017 


\section{International Journal of Science and Research (IJSR) \\ ISSN (Online): 2319-7064 \\ Index Copernicus Value (2015): 78.96 | Impact Factor (2015): 6.391}

low risk management level. Therefore, in the global economy to "low carbon" restructuring, China's commercial banks should conform to the development trend of international banking and adhere to the sustainable development and overall risk management model. Specific measures include improving the green credit system, raising credit policy operability, establishing the risk evaluation mechanism and innovating product and service, so as to adjust the mode of economic development and realize the coordinated development of economy, finance and environment.

\section{References}

[1] Zhang Ye. Countermeasures of developing green credit business of commercial bank [D]. Jilin University, 2013.

[2] An Wei. Preliminary study on the connotation, mechanism and practice of green finance [J]. Journal of Economics, 2008 (05): 156-158.

[3] Ren Hui. Environmental protection, sustainable development and the construction of a green financial system [J]. Financial Finance, 2009 (10): 85-88.

[4] Du Li, Zhang Xin. Green finance, social responsibility and behavior choice of state owned commercial banks [J]. Journal of Social Science of Jilin University, 2012, 52 (5): 82-89.

[5] Dong Xin. Green Finance: existing problems and system construction [J].Contemporary Economic Management, 2015, 37 (9): 94-97.

[6] Kong Rui. Study on the development of green credit in China [D]. Shandong Normal University, 2015.

[7] Changzhou Research Group of the People's Bank of China. Empirical analysis of the effect of implementing green credit policy to guide industrial transformation and upgrading $[\mathrm{J}]$. Finance Vertical and Horizontal, 2013 (6): 26-31.

[8] Yu Lan. Development and innovation of green finance. [J]. Economic Issues, 2016 (1): 78-81.

[9] Huang Jianhuan, Lv Hailong. The impact of financial development on regional green development [J]. Geographical Research, 2014 (3): 532-543.

[10] Tianda Institute Research Group. The green financial system construction and strategic research of [J]. Finance and Development, 2011 (10): 39-46.

[11] Yu Xiaogang. Green credit footprint of China's banking [M]. Beijing: Chinese Environmental Science Press, 2013:11-12.

[12] Weng Zhihong, Ge Chazhong. Comparative study of domestic and international green financial products [J]. China Population: Resources and Environment, 2015 (6) :17-21.

\section{Author Profile}

Zhou Meimei has been studying for a master's degree at the school of economics and management of Xidian University since 2015. The research field is investment and financing theory and practice.

Volume 6 Issue 7, July 2017 www.ijsr.net 